\title{
Implementation and Analysis of Size Korea Projects Using 3D Body Scanning Systems
}

\author{
Chang Kyu PARK*a,b \\ ${ }^{a}$ Department of Textile Engineering, Konkuk University, Seoul, S. Korea \\ ${ }^{\mathrm{b}}$ i-Fashion Biz Center Foundation Ltd, Seoul, S. Korea
}

\begin{abstract}
Recently, 3D body measuring technologies are being developed and various products are being designed actively using 3D anthropometric data. These 3D body measuring technologies is using for national Size project in the world. In this study, thousands people of men and women were measured by using 3D full body scanner, 3D hand scanner, and 3D foot scanner. The purpose of this study is to describe $3 D$ measuring methods using 3D body scanners and 3D anthropometric data in the $6^{\text {th }}$ Size Korea project since 2010.
\end{abstract}

Keywords: 3D body scanning, Size Korea, 3D anthropometric data

\section{Introduction}

Recently with the advance of $3 \mathrm{D}$ body scanners and in response to increasing demand for new anthropometric information and body shape data in rapidly changing industrial environment, 3D body measuring technologies are being developed and various products are being designed actively using 3D anthropometric data.

Japan executed a 3D body measuring project in 1992 and another large-scale one through 2004 to 2006, and the U.S. and the U.K. also collected their people's anthropometric data through SIZE USA in 2002-2003 and SIZE UK in 2001-2002, respectively. Fourth in the world, Korea also collected 3D anthropometric data through the $5^{\text {th }}$ Size Korea project in 2003-2004, and has been executing the $6^{\text {th }}$ Size Korea project using 3D body scanners through four stages for different age groups since 2010 [1]. Using measuring tools like 3D full-body scanner (Hamamatsu BL Scanner and Space Vision 3D Body Scanner ; Japan), 3D hand scanner (EnHAND; Korea) and 3D foot scanner (EnFOOT; Korea), the project collected data on the shapes of full body, head, hand and foot [2]. In this study, we purposed to describe 3D measuring methods using 3D body scanners and 3D anthropometric data in the $6^{\text {th }}$ Size Korea project.

\section{Subjects and measuring tools}

Thousands people participated, and they were divided into men and women and again classified by age. Around 100 people were measured in each group cell by age and gender. The $6^{\text {th }}$ Size Korea project using a 3D body scanning system has been performed as the following stages:

Stage 1 in 2010: 20 - 39 ages (at 5 years' interval)
Stage 2 in 2011: 10 - 19 ages (at 1 year' interval)
Stage 3 in 2012: 40 - 50 ages (at 5 years' interval)

Additionally, Korean male and female soldiers have been measured using 3D body scanning system to develop the best military uniform system in Korea.

The 3D full body scanner is BL Scanner produced by Hamamatsu Company (Japan), which is designed for 3D full body scanning and can detect landmarks and measure automatically (Fig. 1). The measuring range is cylinder-type $185 \mathrm{~cm} \times 100 \mathrm{~cm} \times 60 \mathrm{~cm}$, measuring speed is around 10 seconds, and there are four scan optical heads (infrared LED). Another 3D body scanner used at stage 2 of the $6^{\text {th }}$ Size Korea project is produced by Space Vision (Japan) and has been improved from our requests for the Size Korea project.

The hand scanner is the EnHAND system of K\&I Technology Co., Ltd. (Korea) invented for making customized gloves, etc. by measuring 3D hand data and analyzing the measurement data (Fig. 2). The foot scanner is the EnFOOT system of K\&I Technology Co., Ltd. (Korea) with measuring range of $150^{*} 120^{*} 340(\mathrm{~mm})$, measuring speed of around 18 seconds, and a CCD camera (laser) light source (Fig. 3). 


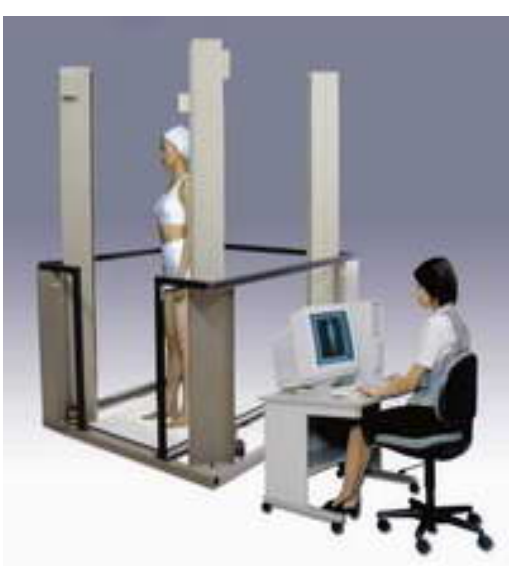

Fig. 1. Hamamatsu BL scanner.

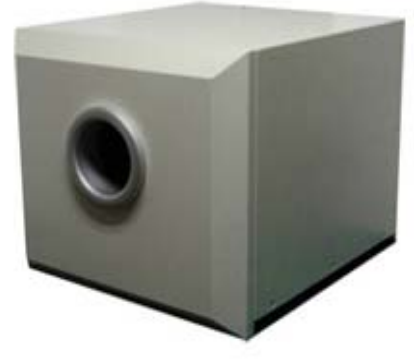

Fig. 2. EnHAN.D

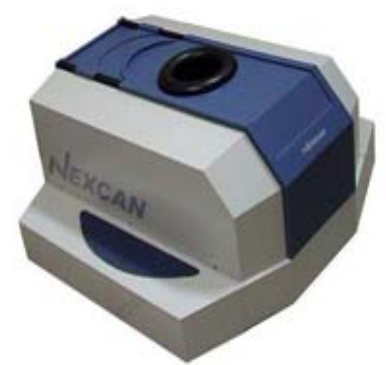

Fig. 3. EnFOO.T

\section{3D body measuring postures and measuring items}

In the $6^{\text {th }}$ Size Korea project, the full body was measured in four postures 'Standing Posture,' 'Erect Posture,' 'Optional Standing Posture' and 'Seated Posture.' In addition, the right hand was used in 3D hand measuring and the right foot in 3D foot measuring, and the head was measured with a measurement hat put on the head bent naturally (Fig. 4). Body measuring items included 15 heights, 21 lengths, 18 circumferences, 9 widths, and 8 thicknesses. In addition, 23 head items, 19 foot items and 19 hand items were measured (Fig. 4).

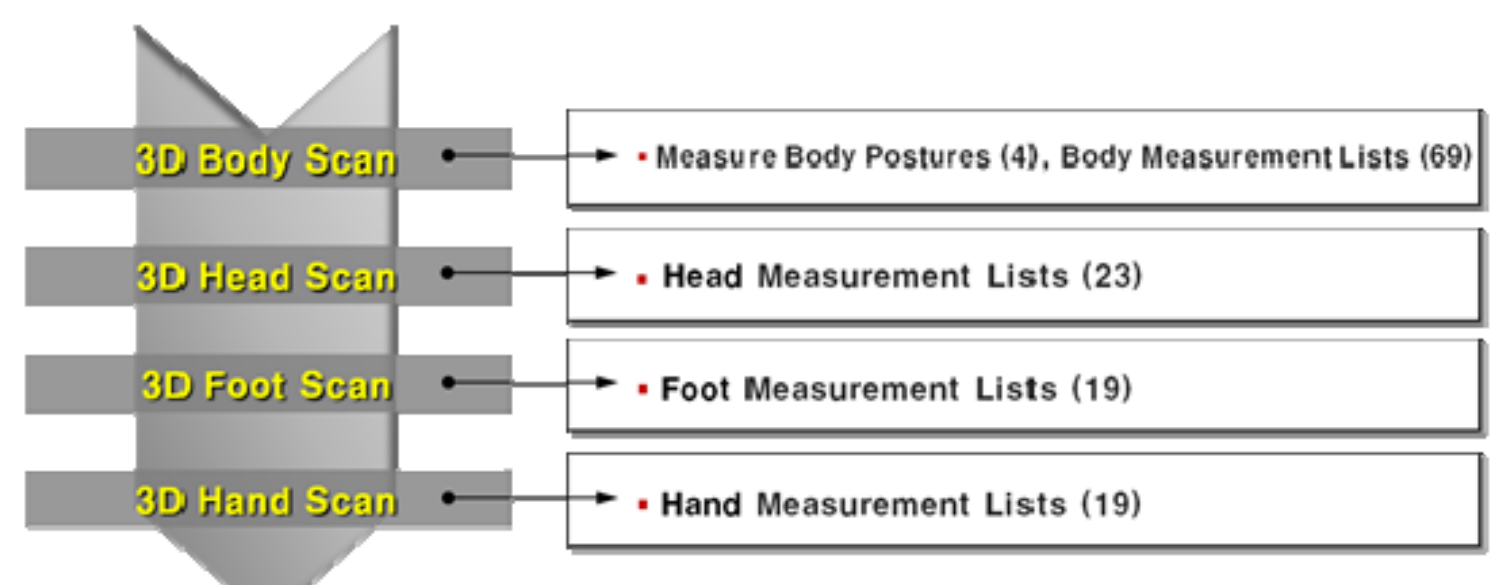

\section{Data Base System}
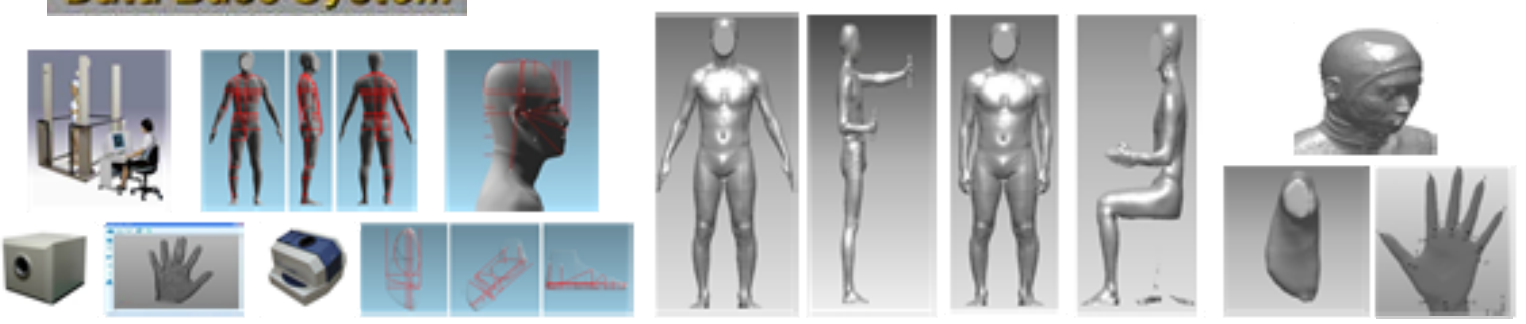

Fig. 4. 3D body measuring postures and measuring items. 
Fig. 5 shows the items of measuring data generated from analyzing anthropometric data based on these measuring items.
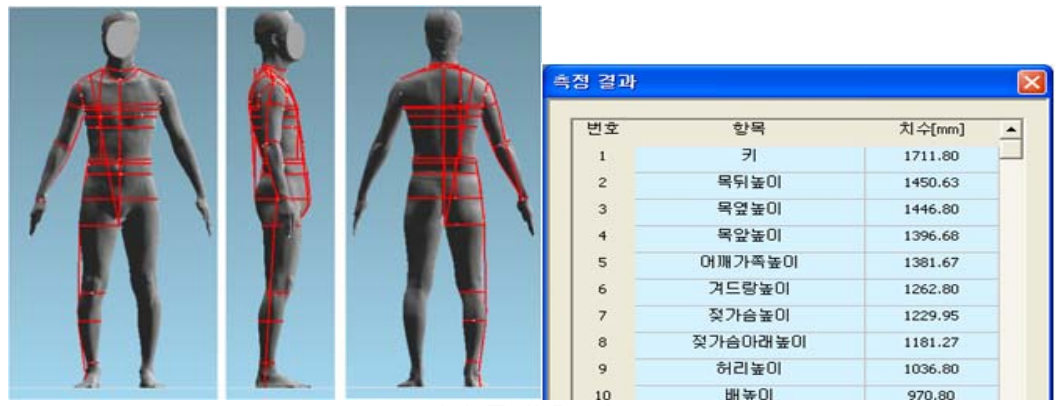

(a) Full Body
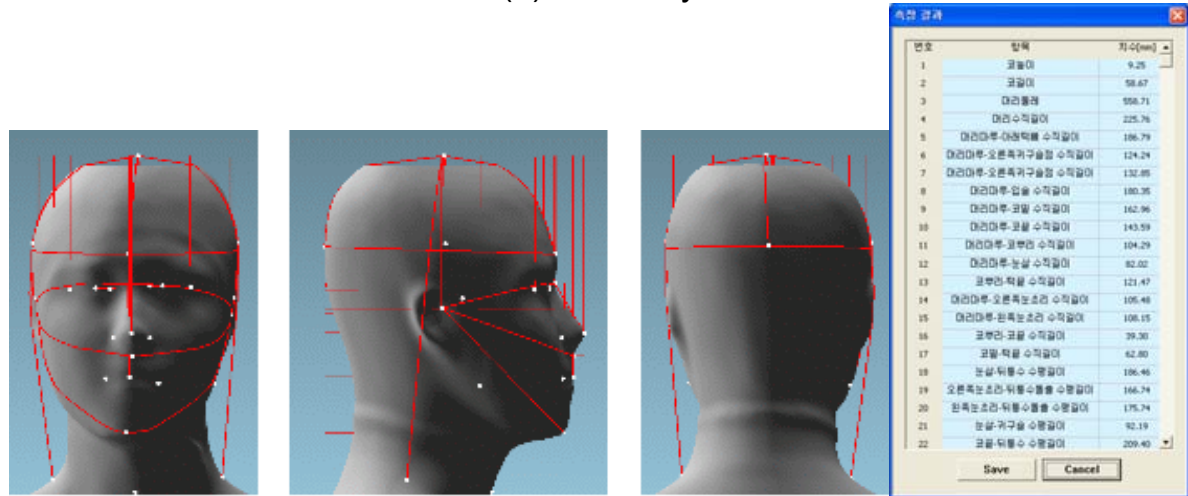

(b) Head

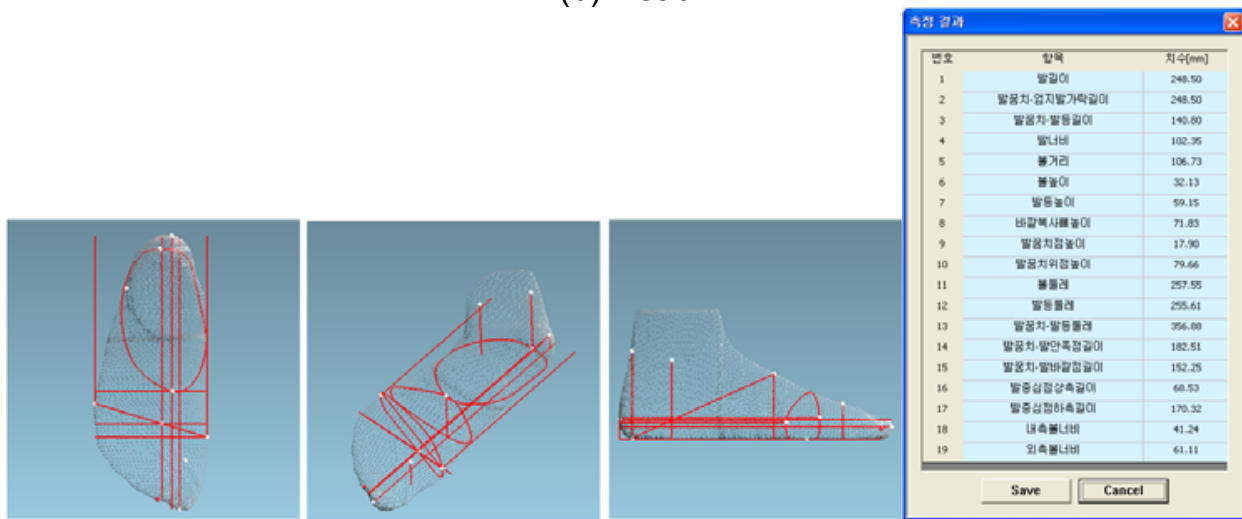

(c) Foot

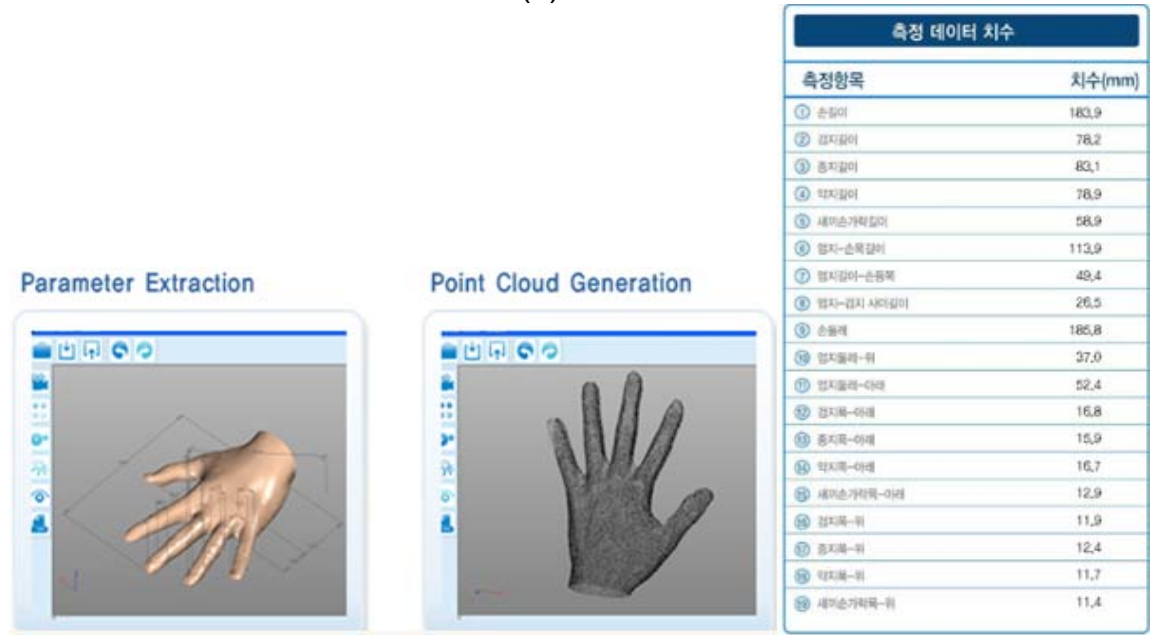

(d) Hand

Fig. 5. Measuring data format for $3 D$ body scan data. 
Through this process, we obtained 3D scan data for body shape, and Table 1 shows the types and sizes of files generated from measuring data and analysis data according to measuring shape.

In the $6^{\text {th }}$ Size Korea project, the full body was measured in four postures 'Standing Posture,' 'Erect Posture,' 'Optional Standing Posture' and 'Seated Posture.' In addition, the right hand was used in 3D hand measuring

Table 1. Measuring shapes and data characteristics.

\begin{tabular}{|c|c|c|c|c|c|}
\hline \multirow{2}{*}{\multicolumn{2}{|c|}{ Item }} & \multicolumn{2}{|c|}{ Measuring Data } & \multicolumn{2}{|c|}{ Analyzing Data } \\
\hline & & \multirow{2}{*}{$\begin{array}{c}\text { File Format } \\
{ }^{*} \text {.abl }\end{array}$} & \multirow{2}{*}{$\begin{array}{l}\text { File Size } \\
\fallingdotseq 10 \mathrm{MB}\end{array}$} & \multirow{2}{*}{$\begin{array}{c}\text { File Format } \\
{ }^{*} \text {.ply }\end{array}$} & \multirow{2}{*}{$\begin{array}{l}\text { File Size } \\
\fallingdotseq 20 \mathrm{MB}\end{array}$} \\
\hline \multirow{12}{*}{$\begin{array}{l}\text { Full } \\
\text { body }\end{array}$} & \multirow{3}{*}{$\begin{array}{l}\text { Standing } \\
\text { Posture }\end{array}$} & & & & \\
\hline & & ${ }^{*}$.iv & $\fallingdotseq 14 \mathrm{MB}$ & *.Ind & $\fallingdotseq 5 \mathrm{~KB}$ \\
\hline & & ${ }^{*} . \mathrm{txt}$ & $\fallingdotseq 3 \mathrm{~KB}$ & ${ }^{*} . \mathrm{csv}$ & $\fallingdotseq 2 \mathrm{~KB}$ \\
\hline & \multirow{3}{*}{ Erect Posture } & ${ }^{\star} . \mathrm{abl}$ & $\fallingdotseq 10 \mathrm{MB}$ & \multirow{3}{*}{\multicolumn{2}{|c|}{ - }} \\
\hline & & *.iv & $\fallingdotseq 14 \mathrm{MB}$ & & \\
\hline & & *.txt & $\fallingdotseq 3 \mathrm{~KB}$ & & \\
\hline & \multirow{3}{*}{$\begin{array}{l}\text { Optional } \\
\text { Standing } \\
\text { Posture }\end{array}$} & ${ }^{*} . \mathrm{abl}$ & $\fallingdotseq 10 \mathrm{MB}$ & \multirow{3}{*}{\multicolumn{2}{|c|}{-}} \\
\hline & & ${ }^{*}$.iv & $\fallingdotseq 14 \mathrm{MB}$ & & \\
\hline & & ${ }^{*} . \mathrm{txt}$ & $\fallingdotseq 3 \mathrm{~KB}$ & & \\
\hline & \multirow{3}{*}{ Seated Posture } & ${ }^{\star} . \mathrm{abl}$ & $\fallingdotseq 10 \mathrm{MB}$ & \multirow{3}{*}{\multicolumn{2}{|c|}{ - }} \\
\hline & & ${ }^{*}$.iv & $\fallingdotseq 13 \mathrm{MB}$ & & \\
\hline & & ${ }^{*} . \mathrm{txt}$ & $\fallingdotseq 2 \mathrm{~KB}$ & & \\
\hline \multirow{4}{*}{\multicolumn{2}{|c|}{ Hand }} & ${ }^{*}$.iv & $\fallingdotseq 14 \mathrm{MB}$ & ${ }^{*} . \operatorname{csv}$ & $\fallingdotseq 2 \mathrm{~KB}$ \\
\hline & & ${ }^{*} . \mathrm{txt}$ & $\fallingdotseq 500 \mathrm{~KB}$ & \multirow{3}{*}{\multicolumn{2}{|c|}{ - }} \\
\hline & & *.nhp & $\fallingdotseq 1 \mathrm{~KB}$ & & \\
\hline & & *.jpg & $\fallingdotseq 210 \mathrm{~KB}$ & & \\
\hline \multirow{3}{*}{\multicolumn{2}{|c|}{ Foot }} & *.enf & $\fallingdotseq 1.3 \mathrm{MB}$ & ${ }^{\star}$. Ind & $\fallingdotseq 2 \mathrm{~KB}$ \\
\hline & & ${ }^{*}$.iv & $\fallingdotseq 400 \mathrm{~KB}$ & \multirow{2}{*}{\multicolumn{2}{|c|}{-}} \\
\hline & & ${ }^{*} \mathrm{nsl}$ & $\fallingdotseq 250 \mathrm{~KB}$ & & \\
\hline \multirow{3}{*}{\multicolumn{2}{|c|}{ Head }} & \multirow{3}{*}{\multicolumn{2}{|c|}{ - }} & ${ }^{*}$.ply & $\fallingdotseq 15 \mathrm{MB}$ \\
\hline & & & & *.Ind & $\fallingdotseq 2 \mathrm{~KB}$ \\
\hline & & & & ${ }^{*} . \mathrm{csv}$ & $\fallingdotseq 2 \mathrm{~KB}$ \\
\hline
\end{tabular}

\section{Conclusion}

As presented above, this study described $3 \mathrm{D}$ body measuring methods in the $6^{\text {th }}$ Size Korea project executed from 2010. In addition, research is being made on how to utilize the 3D body shape data obtained from the project in different industrial areas. We expect that the data may be useful not only in the clothing and fashion industry but also in various other industrial areas including furniture, car, health/diet, game/animation, and advertisement. Research will be continued for the development and application of 3D body measuring technologies and 3D body shape data application and processing to cope with the age of 'ubiquity' and 'mass customization' in the $21^{\text {st }}$ century.

\section{References}

1. Nam, Y. J., Choi, K. M., Jun E. S., Yun, M. H., (2004): "Standardization of 3D body measurement for the Size Korea", Fashion Information and Technology, Vol.1, pp.6-19.

2. Park, C.K., Nam, Y. J., Choi, K. M., Hosun Lim, et al., (2010): "The $6^{\text {th }}$ Size Korea project", Report of the $6^{\text {th }}$ Size Korea project, pp.1-302. 